\title{
The Suitability of Coast Area for the Development of Beach Tourism of Recreation Category at Naku Village, South Leitimur Subdistrict, Ambon City, Indonesia
}

\author{
Daniel Anthoni Sihasale ${ }^{1,2}$,Luchman Hakim ${ }^{1,3}$,Agus Suharyadi ${ }^{1,4}$,Soemarno \\ Soemarno ${ }^{1}$ \\ ${ }^{1}$ Environment Science and Technology Graduate Program, University of Brawijaya, Indonesia \\ ${ }^{2}$ Department of Geography, Faculty of Education, University of Pattimura, Indonesia \\ ${ }^{3}$ Department of Biology, Faculty of Mathematics and Natural Sciences, University of Brawijaya, Indonesia \\ ${ }^{4}$ Department of Civil, Faculty of Engineering, University of Brawijaya, Indonesia
}

\begin{abstract}
Research is carried out at the coast of South Leitimur Subdistrict, Naku Village Coast, Ambon City. The objective of research is to determine the suitability of coast area to the development of beach tourism of recreation category. Method of research is survey with descriptive and evaluative approaches. Data are obtained from primary and secondary data. The suitability of the development of coast area for beach tourism is assigned into 4 (four) classes, which are: Class S1 (Highly Suitable), Class S2 (Quite Suitable), Class S3 (Suitable with Condition) and Class N (Not Suitable). Result of analysis indicates that coast area of Naku Beach has beach area in the Class Highly Suitable (S1) by score total of 146 or $93 \%$. The beach remains between 2 (two) capes on the right and leaf. It has $\square 2.5$ meters depth, white sand (sandy beach) and $\square 15$ meters beach width. Base material of waters is dominated by rock and sand. The current speed is $0.12-0.25$ meters/second with the pattern of long shore current. Beach slope is between 3-6 degrees. The clarity rate of waters is good and therefore, the water base is clearly seen. Land coverage of the beach is dominated by various vegetative such as coconut tree (Cocos nucifera) and ketapang tree (Terminalia catappa). Dangerous biotas such as pig fur (Echinodermata), jellyfish (Chrysaora quinquecirrha), and shark (Carcharhinus) are not found.
\end{abstract}

Keyword: - Suitability; Coast; Beach Touris; South Leitimur; Ambon City

\section{INTRODUCTION}

Indonesia has a very strategic location. It is placed within tropical area and wedged by two continents (Asia and Australia) and two oceans (Hindia and Pacific). It is the biggest country of islands in the world with 17,508 islands, $81,000 \mathrm{~km}$ coastline, and 3.1 millions $\mathrm{km}^{2}$ sea width $(0.3$ million $\mathrm{km}^{2}$ territorial waters, and 2.8 million $\mathrm{km}^{2}$ Nusantara waters). Waters cover $62 \%$ of the territorial width. This strategic location enriches Indonesia with natural resources including the coast [1]. The coast itself is the transition area between land and sea ecosystems. The land side is still influenced by marine processes, including tide and ebb, sea water intrusion, wave, and sea wind. The sea side is influenced with land processes and the impact of human activities such as river water stream, sedimentation and pollution [2].

Beach Tourism is one kind of land usages over coast area which the activity is emphasized on the coast area by using beach natural resources, either in the land side or waters side [3]. Coast area is a socio-ecological system that directly relates to the human component and its ecosystem [4]. Coast tourism itself has some categories of tourism activity, and one of them is beach recreation tourism. Beach recreation is a part of beach tourism which the aim of this recreation is to look for the satisfaction and to eliminate the boredom by having relaxation on the beach [5].

Coast waters must be every important because: (1) almost $38 \%$ of world population are settled by the distance of $100 \mathrm{~km}$ from the beach [6]. By 2020, it is predicted that this number will be similar to the number of adult population on the earth [7], (2) many people always go to the beach for adventurous journey, for relaxing, and for doing activities such as rowing, swimming, snorkeling, and fishing [8], (3) coast area is the physical support to protect the community around the beach from storm wave and sea flood, (4) most fishery activities are occupying the continent base nearby the beach, (5) most oil and gas exploration are taken from the sea base, and (6) beach estuary is the breeding site of many fishes and clams and it is often the habitat of the wild [9]. 
Ambon City is a city in the eastern part of Indonesia. The boundary of 4-miles sea zone is $241.1 \mathrm{~km}^{2}$ or $33.69 \%$ of total width of Ambon City. The surrounding of waters is $82.33 \mathrm{~km}^{2}$, while the length of beach line is $30.12 \mathrm{~km}^{2}$. The natural condition of beach is enriched by the beauty scenery of the coast and sea base. The development of tourism, especially the coast tourism at Ambon City, is implemented almost in whole of coast area. It is conducted in relative with the potential of villages around the coast. There are 5 (five) subdistricts at Ambon City that have been emphasized for such development. One such subdistrict is South Leitimur Subdistrict. In this subdistrict, the salient spot is a wide spread beach with white sand surrounded by natural panorama and highly valuable biodiversity.

Based on the result of survey, it is observed that the potential of coast area in South Leitimur Subdistrict is not entirely developed. Some coasts are not yet touched or even the potential of its natural beach has not been exploited. One such virgin beach is Naku Beach. Indeed, Naku Beach has various panorama including natural beach and beautiful sea base. The existence of this coast has not yet been published generally and not been much known by the community outside Ambon City or the foreigner. Therefore, a research is needed to evaluate the suitability of the land to develop an optimum coast area resource. The development of tourism, especially beach tourism, must be initiated from the planning. This planning itself involves the assessment of the available resource and the potential of tourism attractiveness of the area $[10,11,12,13]$. The development must be related with consideration whether coast area is managed in order to match the usage with land suitability and to keep the harmony of various usages based on ten criteria of coast tourism suitability and recreation type of each activity [14]. The expected product is the beach with the beauty to be enjoyed by tourists [15]. To realize this effort, research is aimed at obtaining information about the coast area of Naku Beach and determining the suitability class of coast area. The development of beach area is then recommended to be the destination of beach tourism.

\section{METHOD}

Research location is Ambon City, precisely at Naku Village, South Leitimur Subdistrict (Figure 1, 2, 3). Naku Village has $5.00 \mathrm{~km}^{2}$, or placed about $1.5 \mathrm{~km}$ or 2 (two) hours to the southern part from the capital of Ambon City. The journey with speedboat only takes 30 minutes. The beach remains within a bay wedged by two rock capes with various vegetative. The sand is finely white and the wave is calm and suitable for swimming. Its geographic position is face to face with Banda Sea. The beauty of the beach is far from being polluted and even with less human touch. It is then possible for visitors to enjoy the originality of beach nature.

Research method is survey method. Survey method is a critical observation to obtain good comments about certain issue in the certain area or location [16]. This method uses descriptive and evaluative approaches. Descriptive method is one research approach to explain the data that are obtained from measurement based on the criteria, while evaluative is one research approach to give an assessment on the studied object. Data sources are primary and secondary data. Primary data include waters depth, beach type, beach width, base material of waters, current speed, beach slope, waters clarity, beach land coverage, dangerous biota, and the distance of freshwater supply [14]. Secondary data involve literatures which are relevant to the research. The instruments used are GPS (Global Positioning System) to determine the geographic position and Abney Level to understand the angle of the slope. The gauge is used to count beach width. The buoyant and stopwatch are employed to calculate current speed, while digital camera is used to take a picture of the existing condition in the field. Correspondence tools are also used.

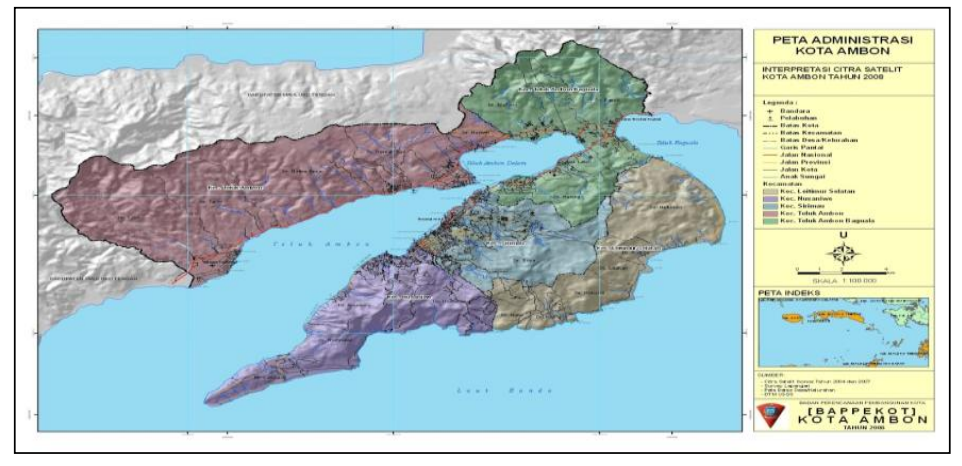

Figure 1. Administrative Map of Ambon City 


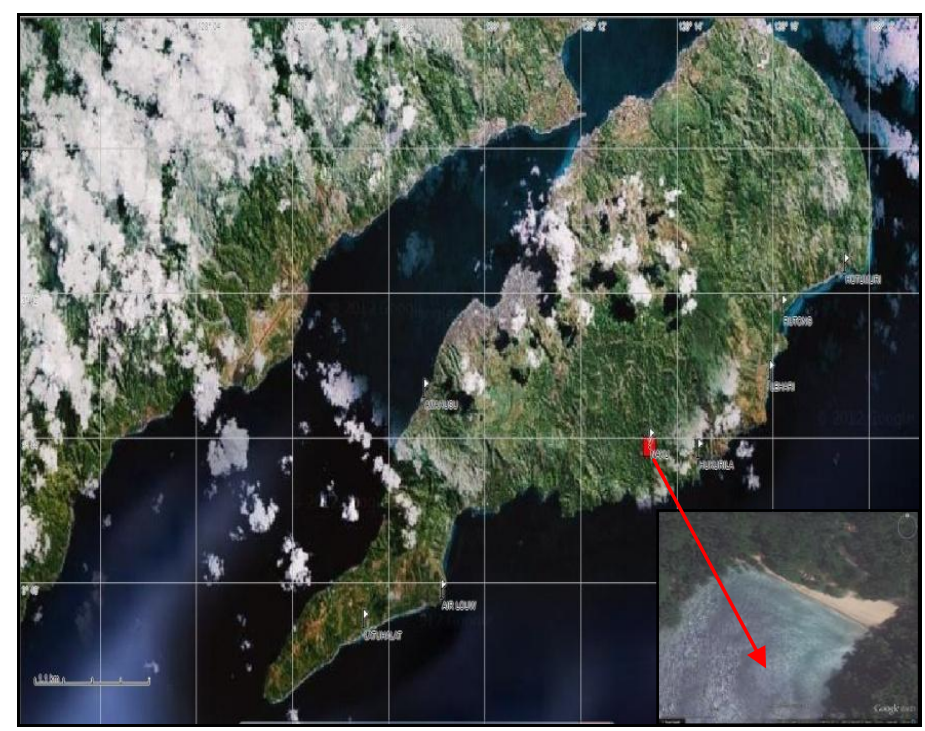

Figure 2. Map of Research Location

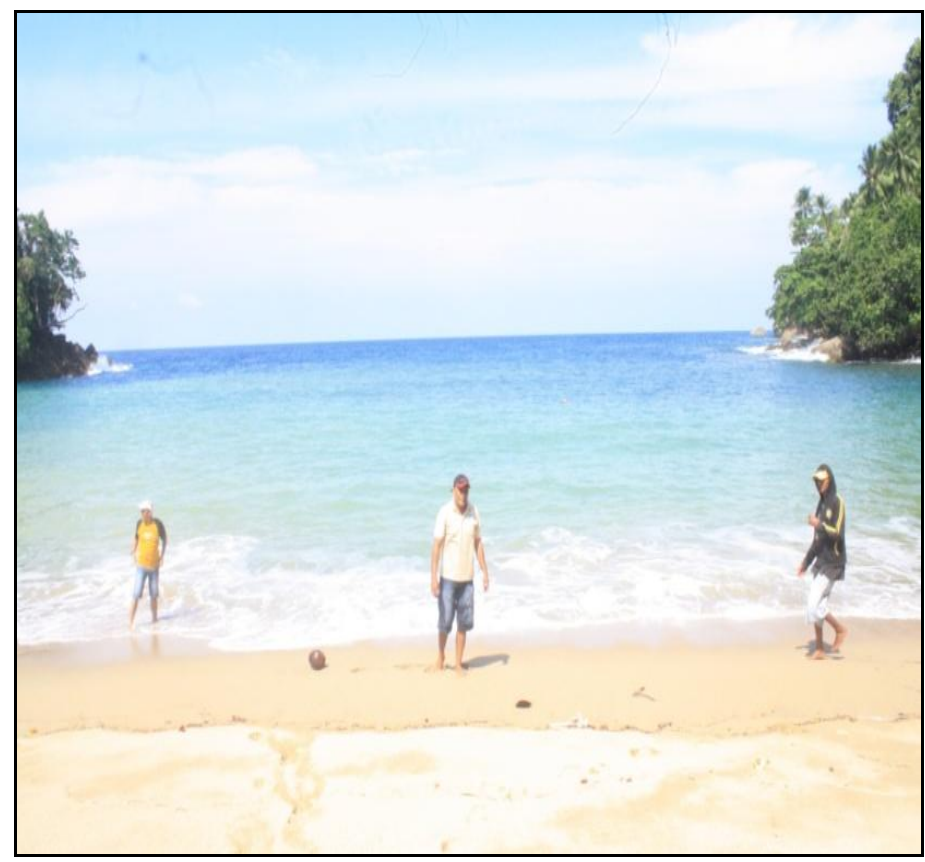

Figure 3. Naku Beach Area, South Leitimur Subdistrict, Ambon City

\section{DATA ANALYSIS}

The analysis of tourism suitability is carried out to ensure the suitability of area for the development of coast area of recreation category. The calculation of Tourism Suitability Index [TSI] (IKW - Indeks Kesesuaian Wisata)[14], by formula:

$\mathrm{TSI}=\sum[\mathrm{Ni} / \max ] \times 100 \%$

Notes:

TSI = Tourism Suitability Index (\%)

$\mathrm{Ni}=$ First parameter (Weight $\mathrm{x}$ Score)

Max = Maximum rate of a tourism category

The parameters as the guide in the development of beach tourism of recreation category are shown in Table 2. 
Table2. The Matrix of The Suitability of Coast Area for Beach Tourism of Recreation Category

\begin{tabular}{|c|c|c|c|c|c|c|c|c|c|c|}
\hline \multirow[t]{2}{*}{ No } & Parameters & \multicolumn{9}{|c|}{ Categories and Scores } \\
\hline & & Weight & Category S1 & Score & Category S2 & Score & Category S3 & Score & Category N & Score \\
\hline 1 & Waters base depth (m) & 5 & $0-3$ & 4 & $>3-5$ & 3 & $>5-10$ & 2 & $>10$ & 1 \\
\hline 2 & Beach type & 5 & White sand & 4 & $\begin{array}{l}\text { White sand, } \\
\text { few rocks }\end{array}$ & 3 & $\begin{array}{l}\text { Rockyblack } \\
\text { sand, little } \\
\text { steep }\end{array}$ & 2 & $\begin{array}{l}\text { Mud with } \\
\text { steep rocks }\end{array}$ & 1 \\
\hline 3 & Beach width $(\mathrm{m})$ & 5 & $>15$ & 4 & $10-15$ & 3 & $3<10$ & 2 & $<3$ & 1 \\
\hline 4 & $\begin{array}{l}\text { Base material of } \\
\text { waters }\end{array}$ & 4 & Sand & 4 & Sandy rocks & 3 & Muddy sand & 2 & Mud & 1 \\
\hline 5 & $\begin{array}{l}\text { Current speed } \\
\text { (m/second) }\end{array}$ & 4 & $0-0.17$ & 4 & $0.17-0.34$ & 3 & $0.34-0.51$ & 2 & $>0.51$ & 1 \\
\hline 6 & Beach slope $\left({ }^{0}\right)$ & 4 & $<10$ & 4 & $10-25$ & 3 & $>25-45$ & 2 & $>45$ & 1 \\
\hline 7 & Waters clarity (\%) & 3 & $>10$ & 4 & $>5-10$ & 3 & $3-5$ & 2 & $<2$ & 1 \\
\hline 8 & Beach land coverage & 3 & $\begin{array}{l}\text { Coconut, } \\
\text { open land }\end{array}$ & 4 & $\begin{array}{l}\text { Shrubs, low } \\
\text { savanna }\end{array}$ & 3 & High shrubs & 2 & $\begin{array}{l}\text { Mangrove, } \\
\text { settlement, } \\
\text { harbor }\end{array}$ & 1 \\
\hline 9 & Dangerous biota & 3 & - & 4 & Pig fur & 3 & $\begin{array}{l}\text { Pig fur, } \\
\text { rayfish }\end{array}$ & 2 & $\begin{array}{l}\text { Pig fur, } \\
\text { ravfish, } \\
\text { shark }\end{array}$ & 1 \\
\hline 10 & $\begin{array}{l}\text { The distance of } \\
\text { freshwater supply } \\
(\mathrm{km})\end{array}$ & 3 & $<05(\mathrm{~km})$ & 4 & $0.5-1(\mathrm{~km})$ & 3 & $>1-2$ & 2 & $>2$ & 1 \\
\hline
\end{tabular}

Notes:

Maximum rate $=156$

Score 4 is given to Category S1 (Very Suitable) with rate $=80-100 \%$ (interval 125-156)

Score 3 is given to Category S2 (Adequate) with rate $=60-<80 \%$ (interval $94-125$ )

Score 2 is given to Category S3 (Suitable with Condition) with rate $=39-<60 \%$ (interval 61-94)

Score 1 is given to Category $\mathrm{N}$ (Not Suitable) with rate $=<39 \%$ (interval $<61$ )

The suitability of coast tourism is assigned into 4 (four) classes such as Highly Suitable (S1), Quite Suitable (S2), Suitable with Condition (S3), and Not Suitable (N). The definition of these classes is following:

Category S1: Highly Suitable. This suitability class does not have the heavy boundary factor for the certain natural use, or if any boundaries, it must be less significant or not significant at all.

Category S2 : Quite Suitable. This suitability class has quite heavy boundary factor for the certain use based on preservation. This boundary factor may influence the satisfaction of tourism activity and even the profit obtained, but it can increase the input of tourism activity.

Category S3: Suitable with Condition. This suitability class has more boundary factors to be met. These boundary factors can reduce satisfaction such that during tourism activity, the boundary factors shall be considered to ensure the stability of ecosystem.

Category N : Not Suitable. This suitability class has truly heavy or permanent boundary factor and therefore, it may be difficult to develop the natural tourism activity.

\section{RESULT AND DISCUSSION}

The Suitability of Coast Area for The Development of Beach Tourism of Recreation Category at Naku Village, South Leitimur Subdistrict, Ambon City. Table 2 in the following shows the calculation of tourism suitability index of the coast in the recreation category, particularly for Naku Beach. The index has 10 (ten) parameters such as: (1) waters depth, (2) beach type, (3) beach width, (4) base material of waters, (5) current speed, (6) beach slope, (7) waters clarity, (8) beach land coverage, (9) dangerous biota, and (10) the distance of freshwater supply [14]. 
Table 3. The Matrix of The Suitability of Coast Area of Naku Beach for Recreation Category

\begin{tabular}{|c|c|c|c|c|c|}
\hline \multirow[t]{2}{*}{ No } & \multirow[t]{2}{*}{ Parameters } & \multirow[t]{2}{*}{ Weight } & \multicolumn{3}{|c|}{ Categories and Scores } \\
\hline & & & Category & Score & Rate \\
\hline 1 & Waters base depth (m) & 5 & $>3-5$ & 3 & 15 \\
\hline 2 & Beach type & 5 & White sand & 4 & 20 \\
\hline 3 & Beach width (m) & 5 & $>15$ & 4 & 20 \\
\hline 4 & Base material of waters & 4 & Sandy rocks & 3 & 12 \\
\hline 5 & Current speed (m/second) & 4 & $0-0.17$ & 4 & 20 \\
\hline 6 & Beach slope $\left({ }^{0}\right)$ & 4 & $<10$ & 4 & 20 \\
\hline 7 & Waters clarity (\%) & 3 & $3-5$ & 2 & 6 \\
\hline 8 & Beach land coverage & 3 & Coconut, open land & 4 & 12 \\
\hline 9 & Dangerous biota & 3 & Nothing & 4 & 12 \\
\hline 10 & $\begin{array}{l}\text { The distance of freshwater supply } \\
(\mathrm{km})\end{array}$ & 3 & $0.5-1(\mathrm{~km})$ & 3 & 9 \\
\hline & Total & 39 & & & 146 \\
\hline
\end{tabular}

$=\frac{\sum[15+20+20+12+20+8+6+12+12+9]}{156} \times 100 \%$

$=\frac{146}{156}=93 \%($ Category S1)

Result of calculation of Tourism Suitability Index (TSI) rate in the coast area of Naku Beach obtains a total score/rate of 146 or $93 \%$. Therefore, Naku Beach is the area which is very suitable (S1) to be developed as the beach tourism area of recreation category. The reviewed parameters for tourism suitability indicate that:

1. Waters depth is the distance from water surface to water base. The depth of waters base of Naku Beach is relatively shallow. The depth is about 10-15 meters and this depth starts about 3-5 meters from the beach. It is the most ideal location for tourism activities such as snorkel ing and swimming [17] and [18] admit that the ideal waters for beach recreation tourism shall be one with 0-5 meters depth. Such waters represent the most ideal location of recreation activities because the visitors can enjoy waters safely.

2. Naku Beach is sandy beach type (Figure 4) with characteristic appearance. It contains loose materials such as sand and silt (gravel). The wave and the current in the beach are the main driver that establishes the type of the beach because it put the sand (or other loose material) continually to the beach.

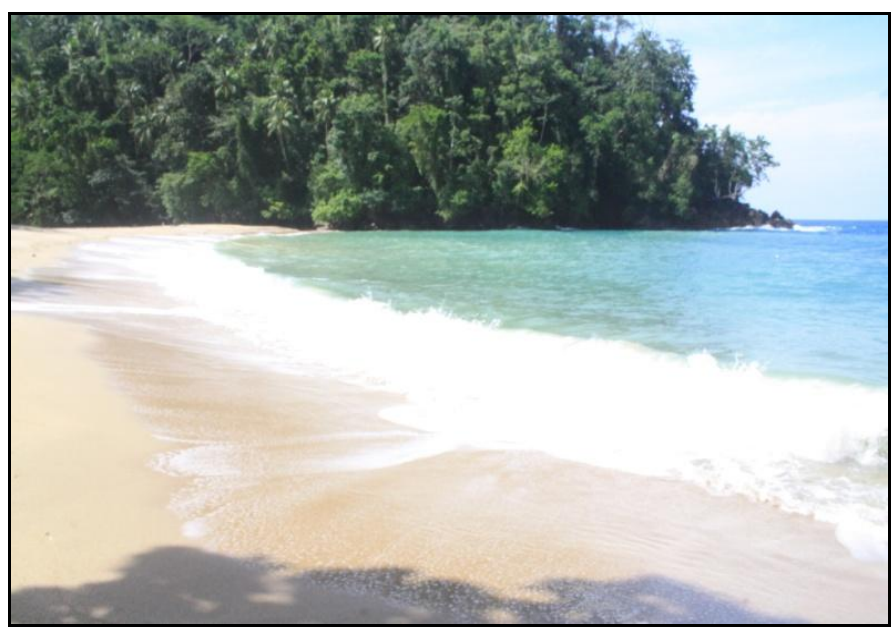

Figure 4. Sandy beach type at Naku Village Beach 
3. The measurement of Naku Beach width is begun from the distance between the last vegetation on the beach and the beach boundary which is still under influence of sea water. The result of measurement indicates that Naku Beach width is \pm 15 meters.

4. Waters base material of Naku Beach is directly influencing the clarity rate of waters. The waters base material is measured by directly observing the waters base. Result of observation shows that waters base material of Naku Beach is dominated by sandy rocks.

5. The maximum speed of current that becomes the standard of snorkeling and swimming activities is maximally 1 (one) knot and 0.51 meters/second. The area with current speed of 0-0.17 meters/second is the most suitable location for coast tourism. The average speed of the current at Naku Beach is 0.12-0.25 meters/second. The pattern of beach current is long shore current. (Figure 5).

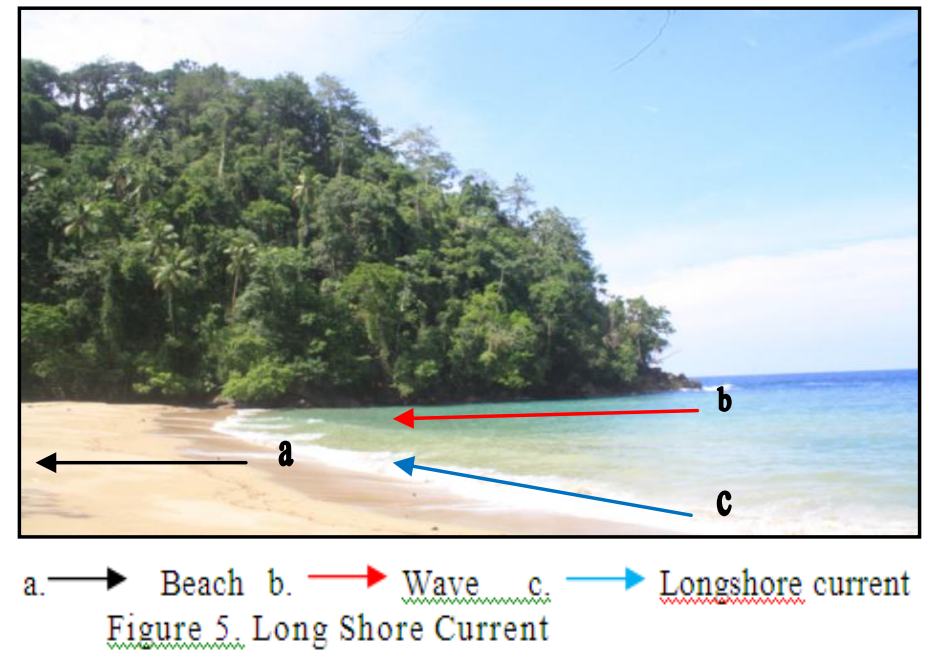

This current pattern is occurred because the wave approaches and hits the beach in the oblique or perpendicular direction to the beach line. The current along the beach moves following the beach, while the rip current moves away from the beach in the perpendicular or oblique direction against the beach line.

6. Naku Beach has configuration of plain land with slight slope, which is only $3-6^{0}$. Material type of coast soil is finely white. The coast is wedged by two capes which are in the right and the left sides of the beach.

7. The clarity of Naku Beach is still influenced by the activity in the waters. In general, Naku Beach is in good condition, the pollutant is absent, and it is natural waters area with lack of human touch. Based on the field observation, it is found that Naku Beach has high clarity rate and it is proved by the clear appearance of the waters base if it is seen from water surface.

8. Land coverage of Naku Beach is various. The coverage is apparent around the beach and at both capes wedging the beach. The plants widely grown around the beach are coconut tree (Cocos nucifera), ketapang tree (Terminalia catappa), and shrubs (Figure 6 and 7).

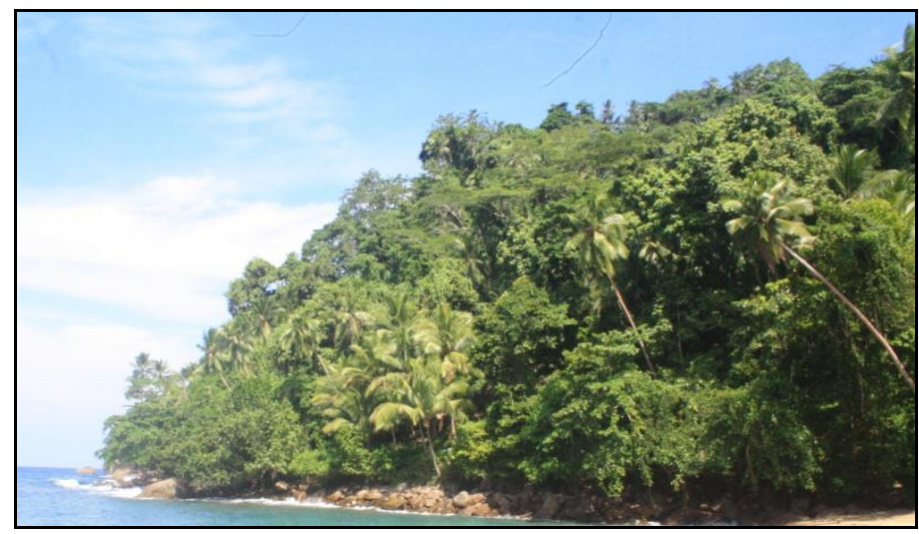

Figure 6. Coconut Tree (Cocos nucifera) in Naku Beach Cape Area 


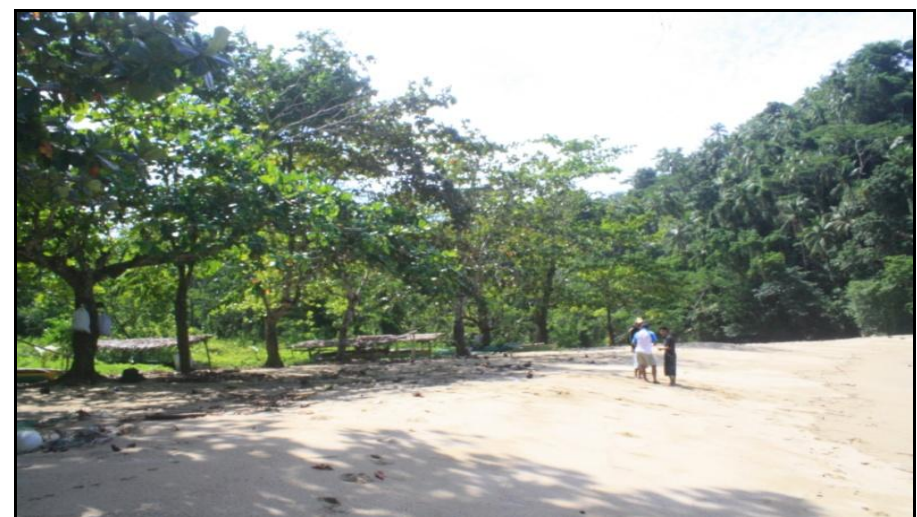

Figure 7. Ketapang Tree (Terminalia catappa) in Naku Beach Cape Area

9. Dangerous biota is not found in Naku Beach. What is called as dangerous biota includes pig fur, jellyfish and shark. These are absent and therefore, the beach is suitable for swimming and snorkeling activities.

10. The distance of freshwater supply in Naku Beach is relatively far away, which is about $1 \mathrm{~km}$ from the source to the beach. The pipeline and water pumping machine, fortunately, allows the people to get freshwater in the location of the beach.

\section{V.CONCLUSION}

The result of survey and analysis over 10 (ten) parameters in Namalatu Beach including waters depth, beach type, beach width, waters base material, current speed, beach slope, waters clarity, beach land coverage, dangerous biota, and the distance of freshwater supply, shows that coast area of Naku Beach is Highly Suitable (S1) for beach tourism by the suitability rate of the area of $93 \%$. It means that the suitability class does not have heavy boundary factor for the certain natural use. If any boundaries, it must be less significant or not significant at all. Therefore, it is concluded that Naku Beach coast area has high potentials to be a destination of beach tourism. The potentials that can be developed are the natural condition of beach, the untouched and unpolluted originality, the distinctive wedged position by 2 (two) capes, and the white sand as well as the diversity of sea vegetations and biotas.

\section{REFERENCES}

[1]. Delinom RM \& Lubis RF. (2007). Air tanah di pesisir dan pulau-pulau kecil. Dalam: Delinom RM,editor. Sumber daya air di wilayah peisisir \& pulau-pulau kecil di Indonesia. Jakarta: LIPI Press. Hall-25.

[2]. Dauri, R.(2002) Pengelolaan Sumber Daya Pesisir Dan lautan Secara Terpadu, (PT. Pradnya Paramita, Jakarta.

[3]. Fandeli, C. (2000). Pengertian dan Konsep Dasar Ekowisata dalam Pengusahaan Ekowisata, Fandel, C. dan Mukhlison (editor). Pusta Pelajar, UGM, Unit Konservasi Sumberdaya Alam (KSDA). Yogyakarta. hlm 127-153.

[4]. Berkes F., and C. Folke, editors. (1998). Linking social and ecological systems, management practices and social mechanisms for building resilience. Cambridge University Press, Cambridge, UK.

[5]. Wahab, S. (1996). Manajemen Kepariwisataan. Cetakan ketiga. Pradnya Paramita. Jakarta.

[6]. Small, C. and J. E. Cohen (2004). Continental Physiography, Climate, and the Global Distribution of Human Population1. Current Anthropology 45 (2).

[7]. Edgren، G. (1993) Expected economic and demographic development in coastal zones world wide in the world coast (eds P.Beukenkamp، P.Gunther/R.Klein et al.) national institute for coastal and marine management، coastal zone management center، Noordwijk، the Netherland

[8]. Crossett, K. M., T. J. Culliton, et al. (2004) Population trends along the coastal United States: (19802008), NOAA National Ocean Service, Management and Budget Office: 54.

[9]. Steward. Robert (2009). Our ocean planet. Oceanography in 21st century. Department of oceanography, texas A\&M university. An online textbook.

[10]. Blank, U. (1989). The community tourism industry imperative. Venture Publishing Inc., State College, PA. 
[11]. Formica, S. (2000). Tourism attractiveness as a function of supply and demand interaction. Unpublished doctoral dissertation, Virginia: Virginia Polytechnic Institute and State University, Blacksburg, Virginia.

[12]. Gunn, C. A. (1994). Tourism Planning (3rd Ed). New York: Taylor and Francis.

[13]. Inskeep, E. (1994). National and Regional Tourism Planning. New York, NY: Routledge.

[14]. Yulianda, F. (2007). Ekowisata Bahari sebagai Alternatif Pemanfaatan Sumberdaya Pesisir Berbasis Konservasi. FPIK IPB. Bogor. Disampaikan pada Seminar Sains 21 Februari (2007) pada Departemen Manajemen Sumberdaya Perairan.

[15]. Sunarto, (1991). Geomorfologi Pantai: Kursus Singkat Pengelolaan dan Perencanaan Bangunan Pantai. Pusat Antar Universitas Ilmu Teknik UGM. Yogyakarta.

[16]. Daniel, M. (2003). Metode Penelitian Sosial Ekonomi. Bumi Aksara. Jakarta.

[17]. Halim, A. (1998). Penentuan Lokasi Wisata Bahari Dengan Sistem Informasi Geografis di Gili Indah Kabupaten Lombok Barat. Propinsi Nusa Tenggara Barat. FPIK.IPB.Bogor. (skripsi S1).

[18]. Haris, A. (2003). Analisis Kesesuaian Lahan dan Kebijakan Pemanfaatan Ruang Wilayah Pesisir Teluk Kayeli Kabupaten Buru. Sekolah Pascasarjana IPB. Bogor. (Tesis S2). 